\title{
SYT1 wt Allele
}

National Cancer Institute

\section{Source}

National Cancer Institute. SYT1 wt Allele. NCI Thesaurus. Code C150331.

Human SYT 1 wild-type allele is located in the vicinity of 12 q21.2 and is approximately 588 $\mathrm{kb}$ in length. This allele, which encodes synaptotagmin-1 protein, plays a role in localization and exocytosis of synaptic vesicles. 